УДК 543.3:550.4(282.256.615)

\title{
ГЕОХИМИЧЕСКИЕ ОСОБЕННОСТИ ПРИРОДНЫХ ВОД БАССЕЙНА РЕКИ ВИТИМ (ЗАПАДНЫЕ РАЙОНЫ ПАТОМСКОГО НАГОРЬЯ)
}

\author{
Новиков Дмитрий Анатольевич1,2, \\ NovikovDA@ipgg.sbras.ru
}

\author{
Максимова Анастасия Алексеевна², \\ rock.nastaya64@gmail.com
}

Напреев Денис Викторович³, dv@mail.ru

\section{Копылова Юлия Григорьевна ${ }^{4}$, unpc_voda@mail.ru}

\author{
Хващевская Альбина Анатольевна 4 , \\ unpc_voda@mail.ru \\ 1 Институт нефртегазовой геологии и геофизики им. А.А. Трофимуука СО РАН, \\ Россия, 630090, г. Новосибирск, пр. Академика Коптюга, 3/6. \\ 2 Новосибирский национальный исследовательский государственный университет, \\ Россия, 630090, г. Новосибирск, ул. Пирогова, 1. \\ 3 ООО Научно-производственное предприятие геофизической аппаратуры «Луч», \\ Россия, 630010, г. Новосибирск, ул. Геологическая, 49. \\ 4 Национальный исследовательский Томский политехнический университет, \\ Россия, 634050, г. Томск, пр. Ленина, 30.
}

\begin{abstract}
Актуальность настоящего исследования связана с получением первых результатов комплексных геохимических исследований природных вод бассейна реки Витим в западных районах Патомского нагорья. Учитьвая широкий спектр выявленных в изучаемом регионе месторождений полезных ископаемых (золота, железа, титана и свинца), возникает два прикладных аспекта применения выполненных исследований. Первый связан с адаптацией гидрогеохимического метода поисков рудных месторождений, а второй - с оценкой антропогенного влияния при разработке месторождений полезных ископаемых и эксплуатации горно-обогатительных предприятий на окружающую среду.

Цель: выявление геохимических особенностей вод бассейна р. Витим и оценка возможных источников поступления элементов в воды.

Методы. Полевое опробование проведено в соответствии с общепринятыми методиками. Химико-аналитические исследования выполнены методами титриметрии, ионной хроматограсрии и масс-спектрометрии с индуктивно связанной плазмой. При анализе информации широко применялись методы математической статистики. Оценка степени концентрирования химических элементов в природных водах проводилась путем расчета коэфффициентов концентрации (Ккі) и водной миграции по А.И. Перельману $\left(K x_{1}\right)$.

Результаты. Приводятся первые данные комплексных гидрогеохимических исследований природных вод бассейна реки Витим (Патомское нагорье). По химическому составу преобладают $\mathrm{SO}_{4}-\mathrm{HCO}_{3} \mathrm{Mg}-\mathrm{Ca}, \mathrm{HCO}_{3} \mathrm{Mg}$-Са воды с величиной общей минерализации от 10 до 298 ма/дм³. Они характеризуются $\mathrm{pH}$ от нейтральных до слабощелочных (6,6-8,0), окислительными условиями геохимической обстановки с Eh от $+155,5$ до +215,9 мB и содержаниями $\mathrm{O}_{2}$ раств. от 4,9 до 8,4 мг/дм³. Рассчитанные коэфффициенты водной миграции химических элементов в изученных водах (средние) выстроились следующим образом в порядке убывания: очень сильная интенсивность миграции $S_{236}>\left.\right|_{37}>B_{26}>c$ сльнаяSbb4,5 $>M_{03,9}>S r_{3,7}>B_{1,0}>c p e d н я я Z n_{0,60}>L i_{0,58}>P_{0,41}>$ $\mathrm{Ba} 0,39>\mathrm{As} 0,32>\mathrm{Cu}_{0,30}>\mathrm{Y}_{0,28}>\mathrm{Sc}_{0,27}>\mathrm{Si}_{0,24}>\mathrm{Mn}_{0,23}>\mathrm{Rb}_{0,22}>\mathrm{Nio}_{0,19}>\mathrm{Be}_{0,18}>\mathrm{Ge}_{0,16}>\mathrm{Co}_{0,16}>\mathrm{Cr}_{0,13}>$ слабая (инертная) интенсивность миграиии $>\mathrm{Fe}_{0,075}>\mathrm{V}_{0,062}>\mathrm{Ga}_{0,049}>\mathrm{Al}_{0,029}>\mathrm{Ti}_{0,012}>\mathrm{Nb}_{0,015}>\mathrm{Zr}_{0,009}$. Профриль выявил сложнопостроенное гидрогеохимическое поле, на которое основное влияние оказывают природные фракторы.
\end{abstract}

\section{Ключевые слова:}

Природные воды, гидрохимия, интенсивность водной миграции элементов, бассейн р. Витим, Патомское нагорье, Сибирская платформа.

\section{Введение}

Бассейн реки Витим расположен на юге Сибирской платформы. Результаты детальных гидрохимических исследований природных вод в научной литературе отсутствуют. Исследуемая территория ограничена ее нижним течением от рабочего поселка Мама до поселка городского типа Витим (рис. 1). Район ис- следований занимает большую площадь (около 7511 км $^{2}$ ) и согласно принятому тектоническому районированию [1] расположен в пределах тектонических структур Байкальской складчатой области (основная часть) и Сибирской платформы. К изучаемому региону относится Витимский железорудный район. Основная минерализация связана с железистыми 
кварцитами и гранитоидами чуйско-нечерского комплекса (U-Pb возраст $1860 \pm 50 \mathrm{Ma})$. В окрестностях расположены два крупных месторождения полезных ископаемых (МПИ) - Холоднинцкое свинцовоцинковое гидротермально-осадочное и прожилкововкрапленное золото-кварцево-сульфидное Сухой Лог $[2,3]$, а также множество мелких месторождений и проявлений. В этой связи возникает два прикладных аспекта применения выполненных исследований. Первый связан с адаптацией гидрогеохимического метода поисков рудных месторождений, а второй - с оценкой антропогенного влияния при разработке
МПИ и эксплуатации горно-обогатительных предприятий на окружающую среду. Последние работы по первому направлению связаны с именами Б.А. Колотова, Н.В. Гусева, Л.К. Мирошниковой, А.В. Паршина, А.Е. Будяка [4-7], а по второму - с Л.В. Глебовой, А.К. Харлашкиной, М.Ю. Ляпунова, М.В. Горюхина, Е.А. Вах [8-11]. Речные системы Сибирской платформы изучаются научными коллективами из Якутска, Москвы, Читы, Иркутска, Владивостока и др. Среди последних публикаций следует отметить следующие [12-17].

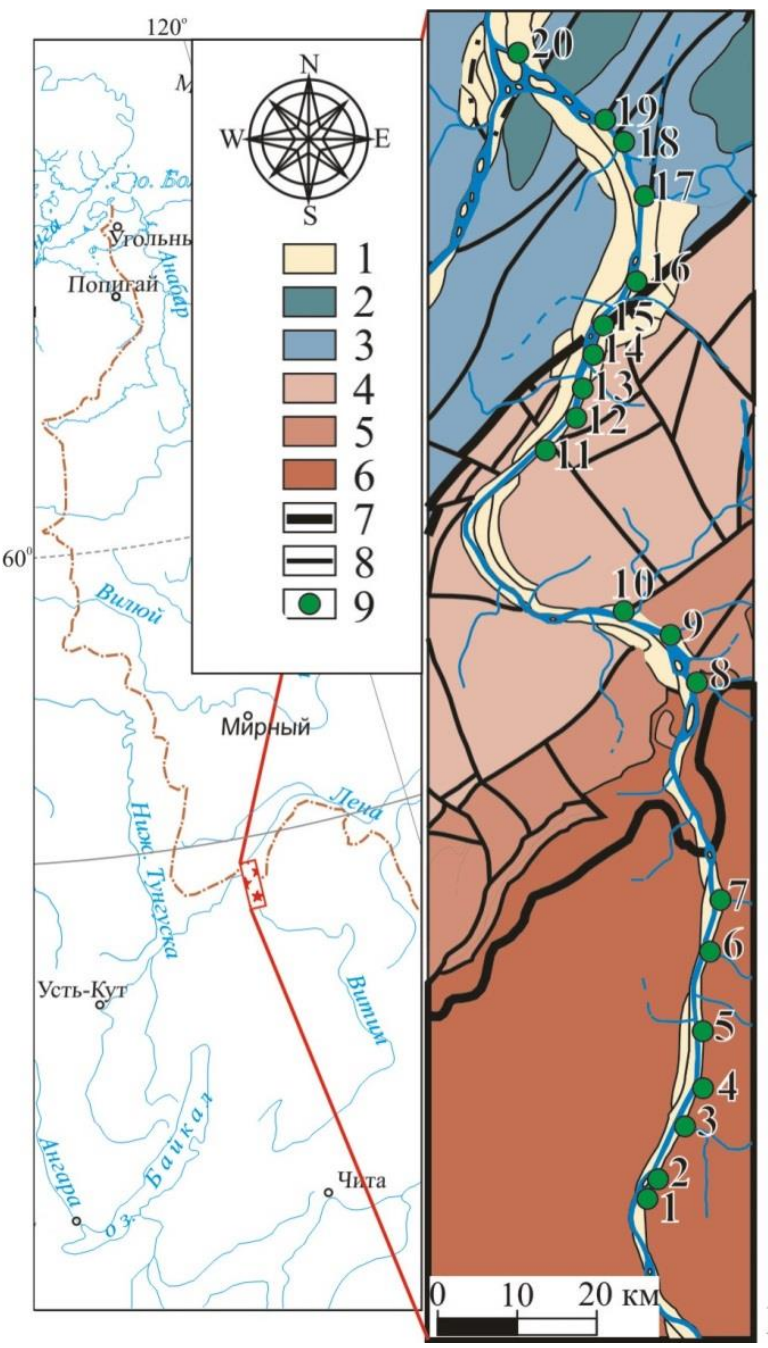

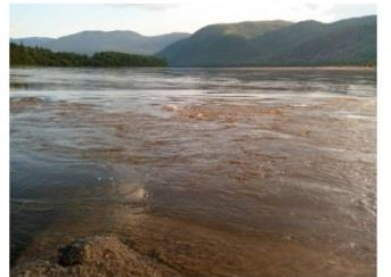
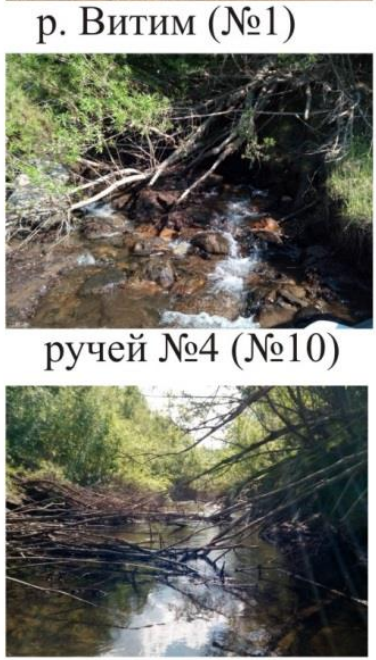

руч. Мысовой (№15)

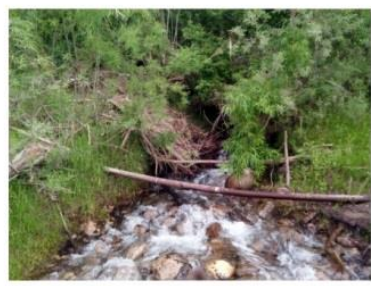

руч. Силинский (№18) устье р.Витим (№20)

Рис. 1. Местоположение района исследования согласно государственной геологической карте Российской Федерации. Масштаб 1:1000000. Лист О 49 [20]. Отложения: 1 - четвертичные; 2 - ордовикские; 3 - кембрийские; 4 - вендские; 5 - рифейские; 6 - чуйско-нечерский гранитоидный комплекс; 7 - надвиги; 8 - разломы; 9 - точки отбора проб воды: 1 - р. Витим, 2 - ручей № 3, 3 - p. Максимиха, 4 - ручей № 2, 5 - ручей № 1 , 6 - р. Иваниха, 7 - p. Барщчиха, 8 - р. Верхняя Язовая, 9 - р. Корюха, 10 - ручей № 4, 11 - p. Теплая, 12 - р. Желтовская, 13 - ручей № 5, 14 - р. Коробова, 15 - руч. Мысовой, 16 - р. Пьлдриха, 17 - p. Быстрая, 18 - руч. Силинский, 19 - р. Дурная, 20 -устье р. Витим

Fig. 1. Location of the research area according to the state geological map of the Russian Federation. Scale 1:1000000. Sheet O 49 [20]. Deposits: 1 - Quaternary; 2 - Ordovician; 3 -Cambrian; 4 -Vendian; 5 - Riphean; 6 - ChuyNechersky granitoid complex; 7 -thrusts; 8 -faults; 9 -water sampling points: 1 - $r$. Vitim, 2 - creek no. 3, 3 -r. Maksimikha, 4 - creek no. 2, 5-creek no. 1, 6-r. Ivanikha, 7 -r. Barshikha, 8 -r. Verkhnyaya Yazovaya, 9 - r. Koryukha, 10 - creek no. 4, $11-r$. Teplaya, $12-r$. Zheltovskaya, 13 - creek no. 5, $14-r$. Korobova, 15 - creek Mysovoy, 16 - r. Pydrikha, 17 - r. Bystraya, 18 - creek Silinsky, 19-r. Durnaya, 20 - r. Vitim outfall 


\section{Фактический материал и методика исследования}

В настоящей работе представлены первые результаты комплексных геохимических исследований природных вод бассейна реки Витим. Отбор проб осуществлялся в период с 26 июня по 4 июля 2019 г. попутно с выполнением сейсморазведочных работ по реке Витим. Геофизическая партия перемещалась по реке на судах типа «Костромич», которые буксировали баржи с установленными на них бытовыми и рабочими сооружениями. Участники исследований выдвигались на моторной лодке для отбора проб в район правых притоков р. Витим, в крупные водотоки заходили в устье и с центральной части реки, пробы отбирались в соответствии с ГОСТ Р 51592-2000 «Вода. Общие требования к отбору проб». Лабораторное изучение химического состава методами титриметрии, ионной хроматографии, масс-спектрометрии с индуктивно связанной плазмой (ИСП) проводилось в Проблемной научно-исследовательской лаборатории гидрогеохимии Инженерной школы природных ресурсов ТПУ (аналитики О.В. Чеботарева, Н.В. Бублий, А.С. Погуца, В.В. Куровская, К.Б. Кривцова, Л.А. Ракул)

Для выявления степени концентрирования химических элементов в природных водах были рассчитаны коэффициенты концентрации $\left(\mathrm{Kk}_{\mathrm{i}}\right)$ и водной миграции по А.И. Перельману $\left(\mathrm{Kx}_{1}\right)$. Первый рассчитывается как: $\mathrm{Kk}_{\mathrm{i}}=\frac{\mathrm{m}_{\mathrm{x}}}{\mathrm{n}_{\mathrm{x}}}$, где $\mathrm{m}_{\mathrm{x}}-$ содержание элемента в воде; $\mathrm{n}_{\mathrm{x}}$ - кларк литосферы в \% (по Н.А. Григорьеву [18]). Второй: $\mathrm{Kx}_{1}=\frac{\mathrm{m}_{\mathrm{x}} \cdot 100}{\mathrm{a} \cdot \mathrm{n}_{\mathrm{x}}}$, [19] где $\mathrm{m}_{\mathrm{x}}-$ содержание элемента в воде (мг/дм $) ;$ a - минерализация (мг/дм $\left.{ }^{3}\right)$ и $\mathrm{n}_{\mathrm{x}}-$ кларк литосферы в $\%$.

\section{Результаты исследования и обсуждение}

Изученные природные воды бассейна р. Витим ультрапресные и умеренно пресные, преимущественно $\mathrm{SO}_{4}-\mathrm{HCO}_{3} \mathrm{Mg}$-Ca, $\mathrm{HCO}_{3} \mathrm{Mg}$-Са состава с величиной общей минерализации от 10 до 298 мг/дм ${ }^{3}$ (табл. 1, рис. 2, a). Формулы Курлова имеют следующий вид (от $10 \%$-экв.):

$$
\begin{aligned}
& \mathrm{pH} 7,4 \frac{\mathrm{HCO}_{3}^{-} 79 \mathrm{SO}_{4}^{2-} 19 \mathrm{Cl}^{-} 2}{\mathrm{Ca}^{2+} 73 \mathrm{Mg}^{2+} 27 \mathrm{Na}^{+} 0,4 \mathrm{~K}^{+} 0,1} ; \\
& \mathrm{pH} 7,4 \frac{\mathrm{HCO}_{3}^{-} 93 \mathrm{SO}_{4}^{2-} 6 \mathrm{Cl}^{-} 1}{\mathrm{Ca}^{2+} 64 \mathrm{Mg}^{2+} 36 \mathrm{Na}^{+} 0,5 \mathrm{~K}^{+} 0,1} .
\end{aligned}
$$

Геохимические параметры (pH, Eh и $\mathrm{O}_{2}$ ) контролируются в первую очередь условиями залегания природных вод и характером их водообмена. Воды характеризуются $\mathrm{pH}$ от нейтральных до слабощелочных $(6,6-8,0)$, окислительными условиями геохимической обстановки с Eh от $+155,5$ до $+215,9 \mathrm{MB}$ и содержаниями $\mathrm{O}_{2 \text { раств. }}$ от 4,9 до $8,4 \mathrm{M \Gamma} /$ дм $^{3}$ и кремния от 0,5 до 4,5 мг/дм ${ }^{3}$. Для сравнения воды реки Алдан (правый приток р. Лены), находящейся к востоку от изучаемых объектов, являются пресными $\mathrm{SO}_{4}-\mathrm{HCO}_{3}$ $\mathrm{Na}-\mathrm{Mg}-\mathrm{Ca} \quad \mathrm{c}$ величиной общей минерализации $86 \mathrm{mг} /$ дм $^{3}$, нейтральными и слабощелочными $\mathrm{pH}$ с содержанием кремния до 3,5 мг/дм ${ }^{3}$ [21], а воды реки Куда, находящейся на юго-западе от изучаемой территории, имеют $\mathrm{SO}_{4}-\mathrm{HCO}_{3} \mathrm{Mg}$-Са состав с величиной общей минерализации от 204-776 мг/дм³ и $\mathrm{pH}$ в интервале 7,3-8,3 [22]. Преобладающими ионами в водах бассейна р. Витим являются $\mathrm{HCO}_{3}, \mathrm{Ca}$ и $\mathrm{Mg}$, концентрации которых не превышают 200, 41 и 18 мг/дм ${ }^{3}$ соответственно. На гидрогеохимическом профиле (водопункты 1-20), в направлении от рабочего поселка Мама до поселка городского типа Витим, происходит рост общей минерализации вод и концентраций основных солеобразующих компонентов (табл. 1, рис. 2,6, ). Гидрохимические данные позволяют выделить две группы водопунктов. Первая (№ 1-9 и 20) объединяет ультрапресные воды с величиной общей минерализации от 10 до 41 мг/дм ${ }^{3}$. Она характеризуется концентрациями $\mathrm{HCO}_{3}$ до $26, \mathrm{Ca}$ до 7,5 и $\mathrm{Mg}$ до $1,4 \mathrm{mг} /$ дм $^{3}$ и содержаниями кремния до 4,5 мг/дм³ ${ }^{3}$ и величиной перманганатной окисляемости 2,04-4,12 мг/дм ${ }^{3}$. Вторая (№ 10-19) включает в себя умеренно пресные воды с величиной общей минерализации от 111 до 298 мг/дм ${ }^{3}$. Они отличаются также более высокими содержаниями $\mathrm{HCO}_{3}$ - до 200, $\mathrm{Ca}$ - до $41 \mathrm{u} \mathrm{Mg}$ - до $18 \mathrm{Mг} /$ дм $^{3}$, но более низкими концентрациями кремния - до 3,5 мг/дм ${ }^{3}$ и водорастворенной органики (перманганатная окисляемость составляет 0,84-1,64 мг/дм³). Среди них по величине перманганатной окисляемости выделяется высокими значениями р. Дурная (№ 19), где она достигает 5,72 мг/дм². В реке Быстрой (№ 17) и ручье Силинском (№ 18) отмечаются относительно высокие содержания ионов хлора и натрия, которые варьируют в диапазоне 7,2-8,8 и 0,42-0,46 мг/дм ${ }^{3}$ соответственно.

Разделение имеющихся данных на однородные геохимические совокупности было выполнено по коэффициентам (Ca/Na, $\mathrm{Ca} / \mathrm{Mg}, \mathrm{Ca} / \mathrm{Si}, \mathrm{Mg} / \mathrm{Si}, \mathrm{Na} / \mathrm{Si}$, $\mathrm{Si} / \mathrm{Na}, \mathrm{rNa} / \mathrm{rCl}$ и $\mathrm{SO}_{4} / \mathrm{Cl}$ ) и позволило выделить пять групп.

В первую (I) группу входят ультрапресные воды четырех объектов (№ 2-5) с величиной общей минерализации от 10 до $23 \mathrm{мг} /$ дм $^{3}, \mathrm{pH}(6,87-7,01)$, Eh $(+172-+212 \mathrm{MB}), \mathrm{O}_{2 \text { раств. }}\left(5,2-7,3 \mathrm{мг} /\right.$ дм $\left.^{3}\right)$ и содержанием $\mathrm{Si} 2,3-4,5$ мг/дм . По отношениям $\mathrm{Ca} / \mathrm{Si}(0,4-1,8)$ и $\mathrm{Si} / \mathrm{Na}(75-79)$ можно предположить, что эти воды дренируют силикатные породы с высоким содержанием кремния.

Вторая (II) группа объединяет преимущественно $\mathrm{SO}_{4}-\mathrm{HCO}_{3} \mathrm{Mg}$-Са воды объектов № 1, 6-9 и $20 \mathrm{c}$ величиной общей минерализации $16-41 \mathrm{m \Gamma} /$ дм $^{3}, \mathrm{pH}$ $6,63-7,52, \mathrm{Eh}+189-+216 \mathrm{mB}, \mathrm{O}_{2 \text { раств }} 4,9-7,8 \mathrm{мг} /$ дм $^{3}$ и содержанием кремния $0,5-1,9$ мг/дм ${ }^{3}$. По составу отличаются воды р. Иванихи (№ 6), имеющие $\mathrm{HCO}_{3} \mathrm{Ca}$ $\mathrm{Mg}$ состав. Вниз по течению $\mathrm{p}$. Витим в этой группе объектов увеличивается отношение $\mathrm{Ca} / \mathrm{Mg}$ от 4,8 до 10,7 .

Третья (III) группа является самой представительной и включает пресные воды восьми объектов (№ 10-17). Величина общей минерализации варьирует в диапазоне 111-205 мг/дм ${ }^{3}$, при изменении $\mathrm{pH}$ от

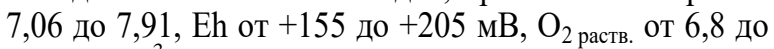
$8,4 \mathrm{Mг} /$ дм $^{3}$ и содержанием кремния в интервале $1,9-3,5 \mathrm{мг} /$ дм$^{3}$. Состав вод в группе меняется с $\mathrm{HCO}_{3}$ $\mathrm{Mg}-\mathrm{Ca}$ на $\mathrm{SO}_{4}-\mathrm{HCO}_{3} \mathrm{Mg}-\mathrm{Ca}$. В корреляции с этим закономерно ведут себя основные геохимические ко- 
эффициенты. Так, отношение $\mathrm{Ca} / \mathrm{Na}$ снижается с 809 до 46, Na/Si растет от 0,009 до 0,160. Средние величины отношений $\mathrm{Ca} / \mathrm{Mg}$ и $\mathrm{Ca} / \mathrm{Si}$ равны 2,8 и 9,2 соответственно. Воды данной группы дренируют в основ- ном карбонатные породы, что выражено в снижении содержания кремния и росте отношения $\mathrm{Ca} / \mathrm{Si}$, тогда как в первой группе наблюдается обратная картина и $\mathrm{Ca} / \mathrm{Si}$ составляет 0,4-1,8.
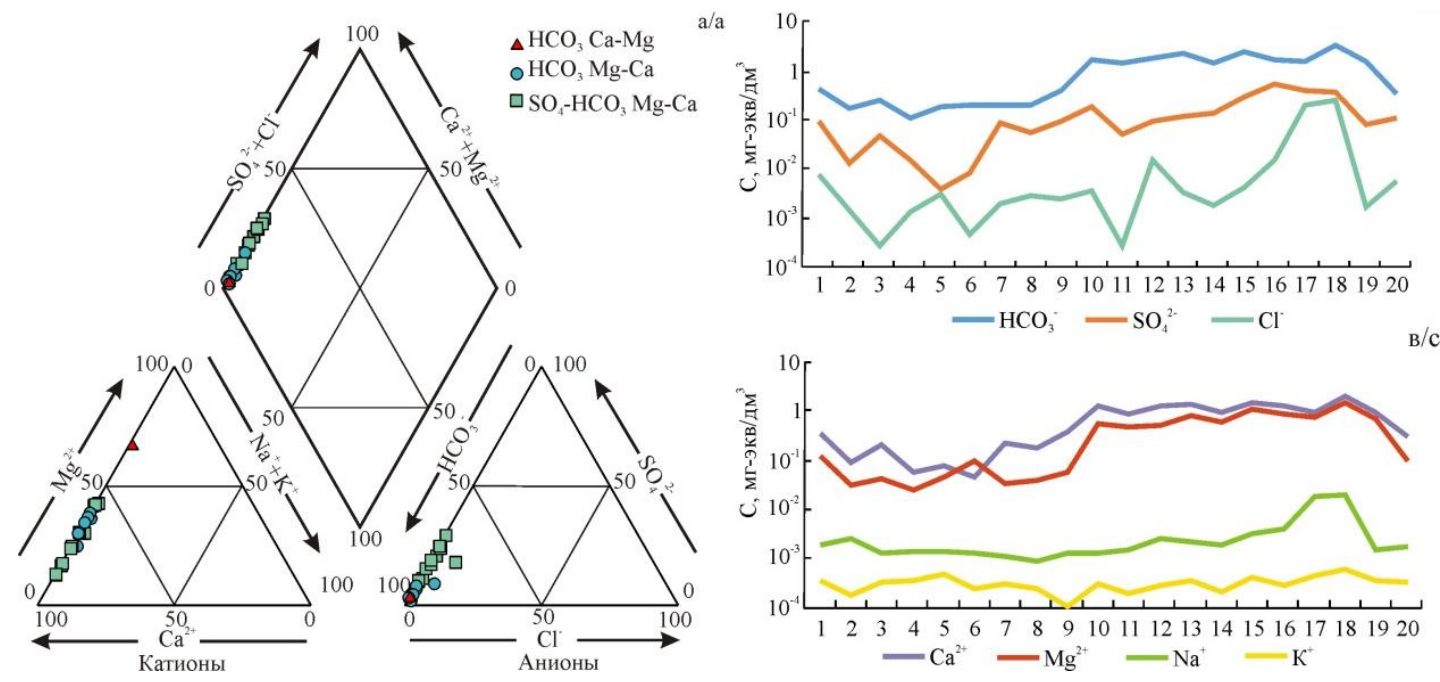

Рис. 2. Диаграмма Пайпера (а) и профиль от пос. Мама до пос. Витим $(б$, в) с нанесением данных по составу природных вод бассейна р. Витим

Fig. 2. Piper diagrams $(a)$ and profile from vil. Mama to vil. Vitim $(b, c)$ with the data on composition of natural waters in the Vitim river basin

Таблица 1. Химический состав природных вод бассейна реки Витим, мг/дм

Table 1. Chemical composition of natural waters in the Vitim river basin, $\mathrm{mg} / \mathrm{l}$

\begin{tabular}{|c|c|c|c|c|c|c|c|c|c|c|c|c|c|c|c|c|}
\hline $\begin{array}{l}\text { № на рис. } 1 \\
\text { № in Fig. } 1\end{array}$ & $\mathrm{pH}$ & $\mathrm{Eh}^{*}$ & П.О. ${ }^{* *}$ & $\mathrm{O}_{2}$ & $\mathrm{HCO}_{3}$ & $\mathrm{SO}_{4}{ }^{2-}$ & $\mathrm{Cl}^{-}$ & $\mathrm{Ca}^{2+}$ & $\mathrm{Mg}^{2+}$ & $\mathrm{Na}^{+}$ & $\mathrm{K}^{+}$ & $\mathrm{NH}_{4}^{+}$ & $\mathrm{NO}_{3}^{-}$ & $\mathrm{Si}$ & $M^{\mathrm{x}}$ & $\begin{array}{l}\text { Химический тип } \\
\text { Chemical type }\end{array}$ \\
\hline 1 & 6,91 & 217,3 & 4,12 & 6,28 & 26 & 4,34 & 0,26 & 7,01 & 1,44 & 0,04 & 0,01 & 0,09 & 0,45 & 1,90 & 41 & $\mathrm{SO}_{4}-\mathrm{HCO}_{3} \mathrm{Mg}-\mathrm{Ca}$ \\
\hline 2 & 7,01 & 202,5 & 3,8 & 7,31 & 10 & 0,61 & 0,05 & 1,79 & 0,37 & 0,06 & 0,01 & 0,17 & 0,10 & 4,53 & 14 & $\mathrm{HCO}_{3} \mathrm{Mg}-\mathrm{Ca}$ \\
\hline 3 & 6,93 & 208,4 & 2,04 & 6,90 & 15 & 2,22 & 0,01 & 4,14 & 0,51 & 0,03 & 0,01 & 0,15 & 0,10 & 2,50 & 23 & $\mathrm{SO}_{4}-\mathrm{HCO}_{3} \mathrm{Mg}-\mathrm{Ca}$ \\
\hline 4 & 6,87 & 190,0 & 2,6 & 6,48 & 7 & 0,71 & 0,05 & 1,14 & 0,31 & 0,03 & 0,01 & 0,15 & 0,18 & 2,27 & 10 & $\mathrm{SO}_{4}-\mathrm{HCO}_{3} \mathrm{Ca}-\mathrm{Mg}$ \\
\hline 5 & 6,92 & 172,2 & 3,72 & 5,17 & 11 & 0,18 & 0,11 & 1,50 & 0,54 & 0,03 & 0,02 & 0,17 & 0,12 & 2,52 & 15 & $\mathrm{HCO}_{3} \mathrm{Mg}-\mathrm{Ca}$ \\
\hline 6 & 6,63 & 211,5 & 2,76 & 6,32 & 12 & 0,40 & 0,02 & 0,94 & 1,22 & 0,03 & 0,01 & 0,15 & 0,10 & 1,42 & 16 & $\mathrm{HCO}_{3} \mathrm{Ca}-\mathrm{Mg}$ \\
\hline 7 & 7,52 & 185,5 & 2,92 & 4,93 & 12 & 4,04 & 0,07 & 4,44 & 0,41 & 0,03 & 0,01 & 0,15 & 0,23 & 0,56 & 22 & $\mathrm{SO}_{4}-\mathrm{HCO}_{3} \mathrm{Mg}-\mathrm{Ca}$ \\
\hline 8 & 7,42 & 184,4 & 2,04 & 7,87 & 12 & 2,61 & 0,10 & 3,57 & 0,48 & 0,02 & 0,01 & 0,11 & 0,10 & 1,55 & 20 & $\mathrm{SO}_{4}-\mathrm{HCO}_{3} \mathrm{Mg}-\mathrm{Ca}$ \\
\hline 9 & 6,93 & 210,7 & 1,16 & 7,61 & 23 & 4,33 & 0,08 & 7,54 & 0,70 & 0,03 & 0,00 & 0,09 & 0,00 & 1,79 & 37 & $\mathrm{SO}_{4}-\mathrm{HCO}_{3} \mathrm{Mg}-\mathrm{Ca}$ \\
\hline 10 & 7,43 & 205,6 & 1,64 & 8,44 & 100 & 9,08 & 0,13 & 24,65 & 6,63 & 0,03 & 0,01 & 0,07 & 0,13 & 3,38 & 142 & $\mathrm{SO}_{4}-\mathrm{HCO}_{3} \mathrm{Mg}-\mathrm{Ca}$ \\
\hline 11 & 7,83 & 176,7 & 1,16 & 7,93 & 84 & 2,46 & 0,01 & 17,47 & 5,65 & 0,04 & 0,01 & 0,05 & 0,10 & 2,80 & 111 & $\mathrm{HCO}_{3} \mathrm{Mg}-\mathrm{Ca}$ \\
\hline 12 & 7,06 & 191,3 & 0,84 & 8,15 & 112 & 4,55 & 0,52 & 24,62 & 6,45 & 0,06 & 0,01 & 0,05 & 0,10 & 2,59 & 150 & $\mathrm{HCO}_{3} \mathrm{Mg}-\mathrm{Ca}$ \\
\hline 13 & 7,49 & 185,5 & 1,32 & 7,81 & 132 & 5,59 & 0,12 & 28,44 & 10,12 & 0,05 & 0,01 & 0,05 & 0,10 & 1,94 & 178 & $\mathrm{HCO}_{3} \mathrm{Mg}-\mathrm{Ca}$ \\
\hline 14 & 7,41 & 178,8 & 0,84 & 7,71 & 88 & 6,48 & 0,06 & 19,22 & 7,39 & 0,04 & 0,01 & 0,05 & 0,10 & 2,14 & 122 & $\mathrm{HCO}_{3} \mathrm{Mg}-\mathrm{Ca}$ \\
\hline 15 & 7,72 & 170,5 & 1,48 & 6,81 & 146 & 13,64 & 0,15 & 29,74 & 13,37 & 0,07 & 0,02 & 0,06 & 0,10 & 2,31 & 205 & $\mathrm{SO}_{4}-\mathrm{HCO}_{3} \mathrm{Mg}-\mathrm{Ca}$ \\
\hline 16 & 7,91 & 160,0 & 1,24 & 8,36 & 98 & 25,67 & 0,55 & 24,74 & 10,88 & 0,09 & 0,01 & 0,05 & 0,13 & 2,22 & 162 & $\mathrm{SO}_{4}-\mathrm{HCO}_{3} \mathrm{Mg}-\mathrm{Ca}$ \\
\hline 17 & 7,86 & 154,4 & 0,84 & 6,88 & 92 & 18,51 & 7,22 & 19,21 & 8,96 & 0,42 & 0,02 & 0,05 & 0,10 & 0,50 & 156 & $\mathrm{SO}_{4}-\mathrm{HCO}_{3} \mathrm{Mg}-\mathrm{Ca}$ \\
\hline 18 & 8,00 & 175,7 & 0,92 & 7,15 & 200 & 17,93 & 8,79 & 41,38 & 18,05 & 0,46 & 0,02 & 0,05 & 0,48 & 1,84 & 298 & $\mathrm{HCO}_{3} \mathrm{Mg}-\mathrm{Ca}$ \\
\hline 19 & 7,33 & 196,6 & 5,72 & 4,14 & 93 & 3,73 & 0,06 & 18,98 & 8,44 & 0,03 & 0,01 & 0,28 & 0,20 & 2,61 & 126 & $\mathrm{HCO}_{3} \mathrm{Mg}-\mathrm{Ca}$ \\
\hline 20 & 7,20 & 200,8 & 3,64 & 6,31 & 20 & 5,12 & 0,20 & 5,86 & 1,13 & 0,04 & 0,01 & 0,15 & 0,20 & 3,56 & 34 & $\mathrm{SO}_{4}-\mathrm{HCO}_{3} \mathrm{Mg}-\mathrm{Ca}$ \\
\hline
\end{tabular}

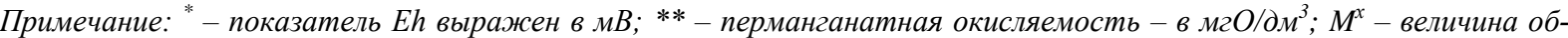
щей минерализации. Наименование химических типов дано в соответствии с формулой М.Г. Курлова (от $10 \%$ \%-экв.). Note: *-Eh is expressed in $\mathrm{mV}$; **-permanganate oxidizability is expressed in $\mathrm{mgO} / \mathrm{dm}^{3} ; \mathrm{M}^{x}-$ the TDS value. The name of the chemical types is given in accordance with the M.G. Kurlov formula (from $10 \%$-eq.).

Значительно отличаются от рассмотренных выше геохимических групп (I-III) ручей Силинский (№ 18) и p. Дурная (№ 19), которые выделены в самостоятельные объекты под номерами IV и V соответственно. Так, воды руч. Силинского (IV, № 18) на гидрогеохимическом профиле характеризуются наиболее высокой минерализацией и $\mathrm{pH}$, равными 298 мг/дм ${ }^{3}$ и 8,0 соответственно (табл. 1). У вод окислительные параметры среды с величиной $\mathrm{Eh}+172 \mathrm{MB}, \mathrm{O}_{2}$ раств. $7,1 \mathrm{мг} /$ дм $^{3}$ и содержанием Si 2,2 мг/дм ${ }^{3}$. Отмечаются высокие отношения $\mathrm{Ca} / \mathrm{Si}(18,6)$ и $\mathrm{Na} / \mathrm{Si}(0,2)$. Воды р. Дурной (V, № 19) имеют величину общей минерализации

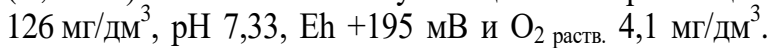
Из рассмотренных вод они отличаются самыми низкими концентрациями кремния - до 0,5 мг/дм ${ }^{3}$, и довольно высокими отношениями $\mathrm{Ca} / \mathrm{Na}(545,1)$ и $\mathrm{Ca} / \mathrm{Si}(40,4)$. 
В представленных объектах впервые изучено распределение широкого спектра химических элементов (от лития до урана). На них кремнию отводится первое место с концентрациями до 4,53 мг/дм ${ }^{3}$ (табл. 1, pис. $3, a)$, отмечается следующее: воды в наибольшей степени обогащены (мг/дм $\left.{ }^{3}\right)$ : $\mathrm{Fe}$ до $0,61, \mathrm{Al}$ до 0,33, $\mathrm{Sr}$ до $0,15, \mathrm{Mn}$ до $0,06, \mathrm{P}$ до 0,04 и Ва до 0,04 , что является логичным, поскольку $\mathrm{Si}, \mathrm{Fe}$ и $\mathrm{Al}$ являются основными элементами континентальной коры. Микрокомпоненты (Ti, B, Br, Zn, Li и $\mathrm{Cr}$ ) характеризуются концентрациями в растворе от 0,002 до $0,014 \mathrm{мг} /$ дм $^{3}$. Группа химических элементов ( $\mathrm{Rb}, \mathrm{I}, \mathrm{Cu}, \mathrm{Se}, \mathrm{Ni}, \mathrm{V}, \mathrm{Y}$, $\mathrm{Sb}, \mathrm{Mo}, \mathrm{Sc}, \mathrm{Co}$ и As) отличается более низкими содержаниями от $1,2 \cdot 10^{-4}$ до $2,5 \cdot 10^{-3}$ мг/дм ${ }^{3}$ и последняя $(\mathrm{Zr}, \mathrm{Ga}, \mathrm{Be}, \mathrm{Ge}$ и $\mathrm{Nb})$ соответствует концентрациям ниже $2,7 \cdot 10^{-4}$ мг/дм ${ }^{3}$. С ростом общей минерализации в растворе накапливаются $\mathrm{Fe}, \mathrm{Al}, \mathrm{Sr}, \mathrm{P}, \mathrm{Mn}, \mathrm{Ba}, \mathrm{Ti}, \mathrm{B}$, $\mathrm{Br}, \mathrm{Li}, \mathrm{Cu}, \mathrm{V}$, As, тогда как содержания $\mathrm{Rb}$ и $\mathrm{Nb}$ снижаются. У $\mathrm{Zn}, \mathrm{Ni}, \mathrm{Mo}, \mathrm{Co}, \mathrm{Zr}, \mathrm{Ga}, \mathrm{Ge}$ и Y отмечено уменьшение концентраций в средней части гидрогеохимического профиля (водопункты с 6 по 15).

В настоящее время в исследуемом районе разработка коренных МПИ не проводится. Поэтому основными источниками поступающих в воды химических элементов являются дренируемые ими горные породы и атмосферные выпадения, при главенствующей роли первых (табл. 2).

В наибольшей мере обогащены микрокомпонентами три изученных объекта. Так, в водах реки Витим (№ 1) выявлены повышенные содержания (до, мг/дм³): $\mathrm{Mn}(0,04), \mathrm{Fe}(0,3), \mathrm{Al}(0,26), \mathrm{Zn}(0,004), \mathrm{Cr}(0,001)$, $\mathrm{Rb}(0,002), \mathrm{Cu}(0,002), \mathrm{Ni}(0,002), \mathrm{Y}(0,0008)$, As $(0,0001)$, $\mathrm{Zr}(0,0003), \mathrm{Ga}(0,0001)$ и $\mathrm{Nb}(0,00002)$; ручья Мысового - Fe $(0,6), \mathrm{Al}(0,3), \mathrm{Mn}(0,06), \mathrm{Ti}(0,01), \mathrm{Cu}(0,001)$ $\mathrm{Ni}(0,0009), \mathrm{Y}(0,001), \mathrm{Sc}(0,0002), \mathrm{Co}(0,0004), \mathrm{Ga}(0,0002)$, $\mathrm{Be}(0,00008)$; реки Пыдриха - Fe $(0,4), \mathrm{Al}(0,3), \mathrm{Mn}(0,02)$, Ti $(0,01), \mathrm{Br}(0,009), \mathrm{Cr}(0,002), \mathrm{Cu}(0,001), \mathrm{V}(0,001)$, Sc $(0,0002)$, As $(0,0003)$, Ga $(0,0002)$.

Таблица 2. Минералогические особенности пород-источников поступления элементов в речные воды

Table 2. Mineralogical features of rocks - sources of entry of elements into river waters

\begin{tabular}{|c|c|c|c|}
\hline $\begin{array}{l}\text { Локализация изу- } \\
\text { ченных объектов } \\
\text { Localization of the } \\
\text { studied objects }\end{array}$ & $\begin{array}{l}\text { Породы } \\
\text { Rocks }\end{array}$ & $\begin{array}{l}\text { Рудные минералы } \\
\text { Ore minerals }\end{array}$ & $\begin{array}{l}\text { Поступающие } \\
\text { элементы } \\
\text { Acting } \\
\text { elements }\end{array}$ \\
\hline $\begin{array}{l}\text { p. Витим } \\
\text { r. Vitim }\end{array}$ & $\begin{array}{l}\text { габброиды, гранитоиды } \\
\text { gabbroids, granitoids }\end{array}$ & $\begin{array}{l}\text { магнетит }\left(\mathrm{FeFe}_{2} \mathrm{O}_{4}\right) \text {, ильменит }\left(\mathrm{FeTiO}_{3}\right) \text {, молибденит } \\
\left(\mathrm{MoS}_{2}\right) \text {, касситерит }(\mathrm{SnO}) \text {, циркон }\left(\mathrm{Zr}\left[\mathrm{SiO}_{4}\right]\right) \text {, } \\
\text { монацит }\left((\mathrm{Ce}, \mathrm{La}, \mathrm{Nd}, \mathrm{Th})\left[\mathrm{PO}_{4}\right]\right), \text { ксенотим }\left(\mathrm{Y}\left[\mathrm{PO}_{4}\right]\right) \\
\text { magnetit }\left(\mathrm{FeFe} \mathrm{O}_{4}\right) \text {, ilmenite }(\mathrm{FeTiO}) \text {, } \\
\text { molybdenite }\left(\mathrm{MoS}_{2}\right) \text {, cassiterite }(\mathrm{SnO}) \text {, zircon }\left(\mathrm{Zr}\left[\mathrm{SiO}_{4}\right]\right) \text {, } \\
\left.\text { monazite }\left((\mathrm{Ce}, \mathrm{La}, \mathrm{Nd}, \mathrm{Th})\left[\mathrm{PO}_{4}\right]\right) \text {, xenotime }\left(\mathrm{Y}^{2} \mathrm{PO}_{4}\right]\right)\end{array}$ & $\begin{array}{l}\text { Fe, Ti, V, Zn, } \\
\text { Mo, Sn, Ag, } \\
\mathrm{Pb}, \mathrm{Be}, \mathrm{Li}, \mathrm{Zr}, \\
\text { Y, Yb, REE, } \\
\quad \mathrm{Nb}\end{array}$ \\
\hline $\begin{array}{l}\text { p. Максимиха } \\
\text { r. Maksimikha }\end{array}$ & $\begin{array}{l}\text { Fе-кварцитогнейсы, Fe- } \\
\text { кварцитосланцы } \\
\text { Fe-quarzite gneiss, Fe-quarzite } \\
\text { shists }\end{array}$ & $\begin{array}{l}\text { гематит }\left(\mathrm{Fe}_{2} \mathrm{O}_{3}\right) \text {, магнетит }\left(\mathrm{FeFe}_{2} \mathrm{O}_{4}\right) \text {, сфалерит }(\mathrm{ZnS}) \text {, } \\
\text { касситерит }\left(\mathrm{SnO}_{2}\right) \\
\text { hematite }\left(\mathrm{Fe}_{2} \mathrm{O}_{3}\right) \text {, magnetit }\left(\mathrm{FeFe}_{2} \mathrm{O}_{4}\right) \text {, sphalerite }(\mathrm{ZnS}) \text {, } \\
\text { cassiterite }(\mathrm{SnO})\end{array}$ & $\mathrm{Fe}, \mathrm{Zn}, \mathrm{Sn}$ \\
\hline $\begin{array}{l}\text { p. Барчиха } \\
\text { r. Barchikha }\end{array}$ & $\begin{array}{l}\text { Fе-кварциты, сланцы, гранито- } \\
\text { иды, кварцевые жилы, грейзе- } \\
\text { низированные гранитоиды, } \\
\text { грейзенизированные плагио- } \\
\text { пегматиты, конгломераты, гра- } \\
\text { велиты } \\
\text { Fe-quarzites, shists, quarz vena, } \\
\text { greisenized granitoids, } \\
\text { plagiopegmatitis, conglomerates }\end{array}$ & 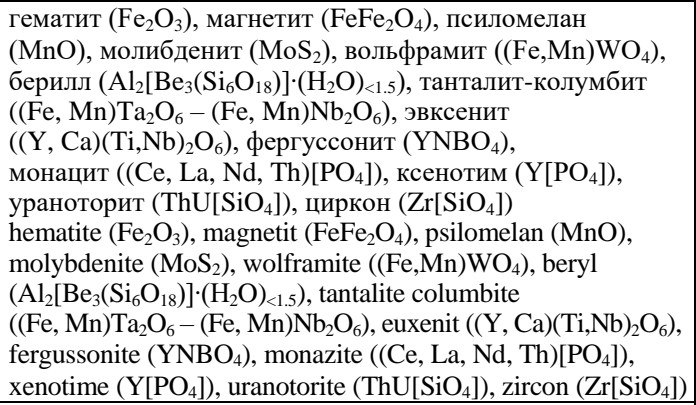 & $\begin{array}{l}\text { Fe, Mn, Al, } \\
\text { Mo, W, Be, } \\
\text { Ta, Nb, Y, Ce, } \\
\text { La, Th, U, Au }\end{array}$ \\
\hline $\begin{array}{l}\text { p. Верх-Язовая } \\
\text { r. Verkh-Yazovaya }\end{array}$ & $\begin{array}{l}\text { Fe-кварциты, конгломераты, } \\
\text { гравелиты, терригенные отло- } \\
\text { жения, кварцевые жилы } \\
\text { Fe-quarzites, conglomerates, } \\
\text { gravelites, terrigenous deposits, } \\
\text { quarz vena }\end{array}$ & $\begin{array}{l}\text { гематит }\left(\mathrm{Fe}_{2} \mathrm{O}_{3}\right) \text {, магнетит }\left(\mathrm{FeFe}_{2} \mathrm{O}_{4}\right) \text {, циркон }\left(\mathrm{Zr}\left[\mathrm{SiO}_{4}\right]\right) \text {, } \\
\text { рутил }\left(\mathrm{TiO}_{2}\right), \text { ильменит }\left(\mathrm{FeTiO}_{3}\right) \text {, вольфрамит } \\
\left((\mathrm{Fe}, \mathrm{Mn}) \mathrm{WO}_{4}\right) \text { hematite }\left(\mathrm{Fe}_{2} \mathrm{O}_{3}\right), \text { magnetit }\left(\mathrm{FeFe}_{2} \mathrm{O}_{4}\right), \\
\text { zircon }\left(\mathrm{Zr}\left[\mathrm{SiO}_{4}\right]\right) \text {, rutile }\left(\mathrm{TiO}_{2}\right) \text {, ilmenite }\left(\mathrm{FeTiO}_{3}\right) \\
\text { wolframite }\left((\mathrm{Fe}, \mathrm{Mn}) \mathrm{WO}_{4}\right)\end{array}$ & $\begin{array}{c}\mathrm{Fe}, \mathrm{Mn}, \mathrm{W}, \mathrm{Y}, \\
\mathrm{Yb}, \mathrm{Au}\end{array}$ \\
\hline $\begin{array}{l}\text { p. Дурная } \\
\text { r. Durnaya }\end{array}$ & $\begin{array}{l}\text { россыпи золота } \\
\text { placers of gold }\end{array}$ & & $\mathrm{Au}$ \\
\hline
\end{tabular}

Среди геологических факторов литологоминералогические особенности водовмещающих пород выступают основными при протекании процессов формирования химического состава природных вод. Для оценки степени накопления в водах химических элементов были рассчитаны коэффициенты концентрации, которые выявили следующий ряд (рис. 3, б): $\operatorname{Se}\left(9 \cdot 10^{-3}\right)>\operatorname{Sb}\left(3 \cdot 10^{-3}\right)>\operatorname{I}\left(1 \cdot 10^{-3}\right)>\operatorname{Br}\left(1 \cdot 10^{-3}\right)>\mathrm{B}\left(2 \cdot 10^{-4}\right)>\mathrm{Sr}$ $\left(2 \cdot 10^{-4}\right)>$ Mo $\left(2 \cdot 10^{-4}\right)>\operatorname{As}\left(5 \cdot 10^{-5}\right)>\operatorname{Li}\left(3 \cdot 10^{-5}\right)>\operatorname{Ba}\left(2 \cdot 10^{-5}\right)>\mathrm{Zn}$ $\left(2 \cdot 10^{-5}\right)>\mathrm{Sc}\left(1 \cdot 10^{-5}\right)>\mathrm{P}\left(1 \cdot 10^{-5}\right)>\mathrm{Mn}\left(1 \cdot 10^{-5}\right)>\mathrm{Cu}\left(1 \cdot 10^{-5}\right)>\mathrm{Co}$ $\left(1 \cdot 10^{-5}\right)>\mathrm{Y}\left(1 \cdot 10^{-5}\right)>\mathrm{Ni}\left(8 \cdot 10^{-6}\right)>\mathrm{Ge}\left(8 \cdot 10^{-6}>\mathrm{Si}\left(7 \cdot 10^{-6}\right)>\mathrm{Cr}\right.$ $\left(6 \cdot 10^{-6}\right)>\operatorname{Rb}\left(4 \cdot 10^{-6}\right)>\operatorname{Be}\left(3 \cdot 10^{-6}\right)>\mathrm{V}\left(3 \cdot 10^{-6}\right)>\mathrm{Fe}\left(3 \cdot 10^{-6}\right)>\mathrm{Ga}$ $\left(3 \cdot 10^{-6}\right)>\operatorname{Al}\left(1 \cdot 10^{-6}\right)>\operatorname{Ti}\left(6 \cdot 10^{-7}\right)>\operatorname{Zr}\left(4 \cdot 10^{-7}\right)>\mathrm{Nb}\left(3 \cdot 10^{-7}\right)$. Учитывая крайне малое время взаимодействия в системе вода - горная порода, в водах не наблюдается значимых величин концентрирования элементов. Максимальные значения Kki установлены у $\mathrm{Se}, \mathrm{Sb}, \mathrm{I}$ и $\mathrm{Br}\left(\mathrm{n} \cdot 10^{-3}\right)$; средние у As, Li, Ba, Zn, Sc, P, Mn, Cu, Co, $\mathrm{Y}\left(\mathrm{n} \cdot 10^{-5}\right)$, а минимальные у $\mathrm{Ti}, \mathrm{Zr}, \mathrm{Nb}\left(\mathrm{n} \cdot 10^{-7}\right)$. 

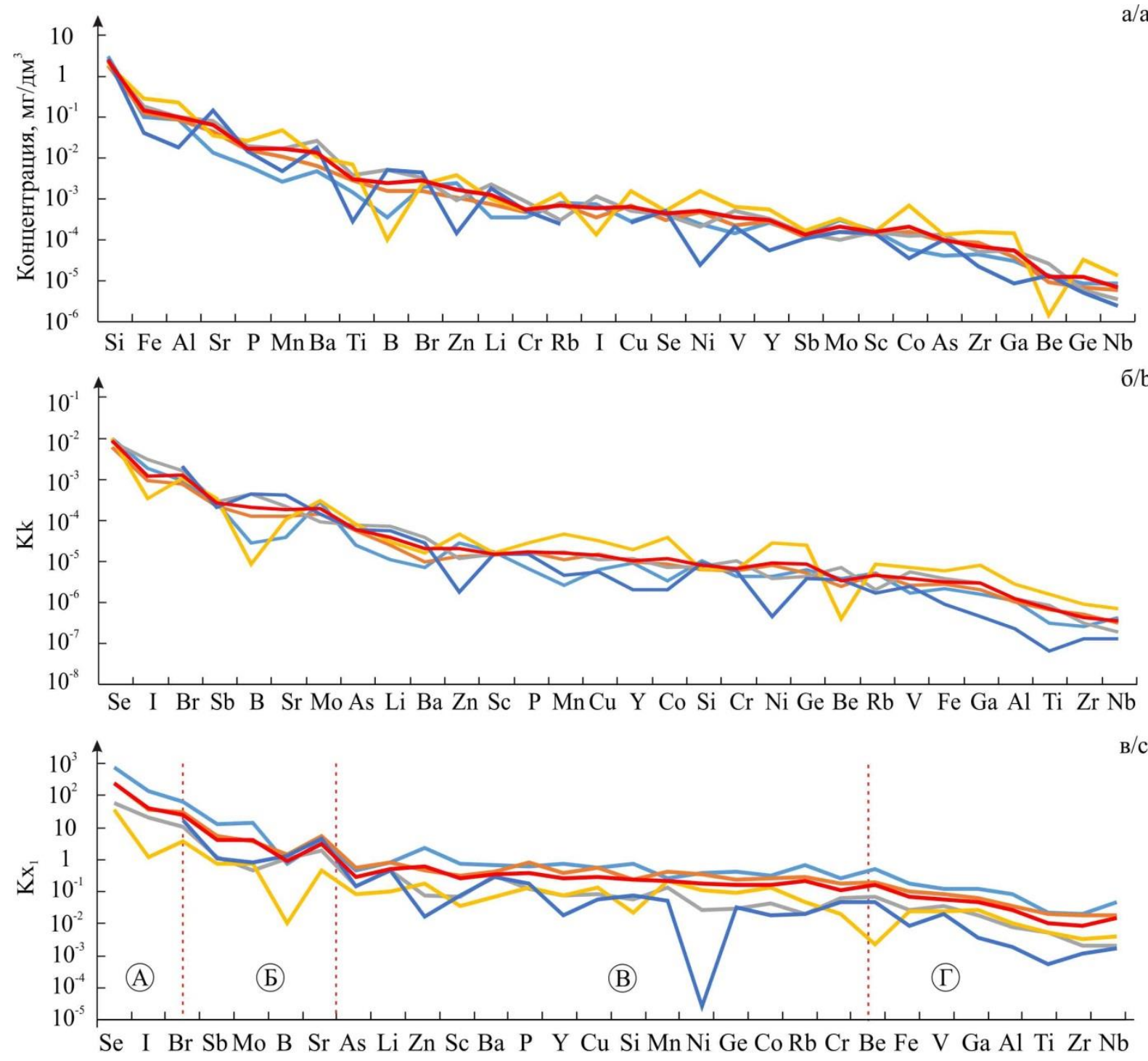

$$
\text { - I - II —III - IV - V - Среднее }
$$

Puc. 3. Спектр распределения микрокомпонентов в водах бассейна р. Витим (a), распределение коэффициентов концентрачий (б), ряды миграчии микрокомпонентов в природных водах (в). Описание геохимических групп природных вод дано в тексте. Ряды миграции микрокомпонентов в природных водах (по А.И. Перельману [23]): A-высокоподвижные элементы; 5 -легкоподвижные; $B$ - подвижные; $\Gamma$-инертные

Puc. 3. Distribution spectrum of trace elements in the waters in the Vitim river basin (a), distribution of concentration factors (b), microelements migration series in natural waters (c). Description of the geochemical groups of natural waters is given in the text. Microelements migration series in natural waters (according to A.I. Perelman [23]): Ahighly mobile elements; $B$-easy mobile; $C$-mobile; $D$-inert

А.И. Перельманом [23] был предложен метод оценки водной миграции химических элементов в зоне гипергенеза по коэффициенту $\left(\mathrm{Kx}_{1}\right)$, который определяется как отношение содержания химического элемента в минеральном остатке воды к его содержанию в водовмещающих породах или кларку литосферы. Этот коэффициент отражает интенсивность водной миграции, определяемую свойствами самого элемента, а также степень его концентрирования или рассеяния в природных водах. Для расчетов были использованы кларки литосферы [18]. Так, усредненные значения коэффициентов водной миграции химических элементов в изученных водах (рис. 3, в) выстроились следующим образом: очень сильная интенсивность $\mathrm{Se}_{236}>\mathrm{I}_{37}>\mathrm{Br}_{26}>$ сильная $\mathrm{Sb}_{4,5}>\mathrm{Mo}_{3,9}>\mathrm{Sr}_{3,7}>\mathrm{B}_{1,0}>$ средняя $\mathrm{Zn}_{0,60}>\mathrm{Li}_{0,58}>$ $\mathrm{P}_{0,41}>\mathrm{Ba}_{0,39}>\mathrm{As}_{0,32}>\mathrm{Cu}_{0,30}>\mathrm{Y}_{0,28}>\mathrm{Sc}_{0,27}>\mathrm{Si}_{0,24}>\mathrm{Mn}_{0,23}>$ $\mathrm{Rb}_{0,22}>\mathrm{Ni}_{0,19}>\mathrm{Be}_{0,18}>\mathrm{Ge}_{0,16}>\mathrm{Co}_{0,16}>\mathrm{Cr}_{0,13}>$ слабая (инертная) $>\mathrm{Fe}_{0,075}>\mathrm{V}_{0,062}>\mathrm{Ga}_{0,049}>\mathrm{Al}_{0,029}>\mathrm{Ti}_{0,012}>\mathrm{Nb}_{0,015}>\mathrm{Zr}_{0,009}$.

В сравнении с предложенными А.И. Перельманом рядами миграции в изученных водах селен переходит в группу высокоподвижных из группы легкоподвижных. Рост концентраций селена по гидрогеохимическому профилю от $9,9 \cdot 10^{-5}$ до $3,9 \cdot 10^{-4} \mathrm{M \Gamma} /$ дм $^{3}$ может быть связан с его поступлением из вмещающих пород с сульфидной минерализацией в форме гидроселенидиона $\left(\mathrm{HSeO}_{3}\right)$ и оксида селена $\left(\mathrm{SeO}_{3}{ }^{2-}\right)$ [24-35], что согласуется с принятыми при анализе геохимических данных Eh-pH диаграммами [36-38]. 


\section{Заключение}

Резюмируя вышесказанное, отметим, что изученные воды бассейна реки Витим ультрапресные и умеренно пресные, преимущественно $\mathrm{SO}_{4}-\mathrm{HCO}_{3} \mathrm{Mg}-\mathrm{Ca}$, $\mathrm{HCO}_{3} \mathrm{Mg}-\mathrm{Ca}$ состава с величиной общей минерализации от 10 до 298 мг/дм³. Воды характеризуются рН от нейтральных до слабощелочных и Eh, отвечающим окислительным условиям геохимической обстановки.

В водах бассейна р. Витим преобладают: $\mathrm{HCO}_{3}, \mathrm{Ca}$ и $\mathrm{Mg}$, концентрации которых не превышают 200, 41 и $18 \mathrm{мг} /$ дм $^{3}$ соответственно. По составу и величине общей минерализации выделяются две группы. Первая (№ 1-9 и 20) включает ультрапресные воды с величиной общей минерализации от 10 до 41 мг/дм ${ }^{3}$, с концентрациями $\mathrm{HCO}_{3}$ от 6,7 до 26, Са от 1,1 до 7,5 и $\mathrm{Mg}$ от 0,3 до 1,4 мг/дм ${ }^{3}$, содержаниями кремния и органического вещества, достигающими 4,5 и 4,12 мг/дм соответственно. Вторая (№ 10-19) объединяет умеренно пресные воды с величиной общей минерализации от 111 до 298 мг/дм ${ }^{3}$, с концентрациями $\mathrm{HCO}_{3}$ от 84 до 200, Са от 17 до 41 и $\mathrm{Mg}$ от 6 до 18 мг/дм ${ }^{3}$, содержаниями $\mathrm{Si}$ и органического вещества, составляющими 3,5 и 1,6 мг/дм ${ }^{3}$ соответственно.

Анализ геохимических коэффициентов $(\mathrm{Ca} / \mathrm{Na}$, $\mathrm{Ca} / \mathrm{Mg}, \mathrm{Ca} / \mathrm{Si}, \mathrm{Mg} / \mathrm{Si}, \mathrm{Na} / \mathrm{Si}, \mathrm{Si} / \mathrm{Na}, \mathrm{rNa} / \mathrm{rCl}$ и $\mathrm{SO}_{4} / \mathrm{Cl}$ ) позволил выделить пять групп. Первая (I) группа характеризуется отношениями $\mathrm{Ca} / \mathrm{Si}(0,4-1,8)$ и $\mathrm{Si} / \mathrm{Na}$ (75-79), что указывает на дренирование водами силикатных пород с высоким содержанием кремния. Во второй (II) группе увеличивается отношение $\mathrm{Ca} / \mathrm{Mg}$ от 4,8 до 10,7. В третьей (III) группе средние отношения $\mathrm{Ca} / \mathrm{Mg}$ и $\mathrm{Ca} / \mathrm{Si}$ равны 2,8 и 9,2 соответственно, а также возрастает $\mathrm{Ca} / \mathrm{Si}$ отношение $(0,4-1,8)$. В водах руч. Силинского (IV, № 18) отмечаются высокие отношения $\mathrm{Ca} / \mathrm{Si}(18,6)$ и $\mathrm{Na} / \mathrm{Si}(0,2)$. А воды р. Дурной

\section{СПИСОК ЛИТЕРАТУРЬ}

1. Хаин В.Е. Тектоника континентов и океанов (год 2000). - М.: Научный мир, 2001. - 606 c.

2. Иванов А.И. Рифейско-палеозойское рудообразование в Байкало-Патомской золоторудной провинции // Разведка и охрана недр. - 2009. - № 12. - С. 3-10.

3. Архангельская В.В. Месторождения полезных ископаемых Патомского нагорья и их структурное положение // Разведка и охрана недр. - 2012. - № 4. - С. 6-10.

4. Колотов Б.А. Научные основы гидрогеохимического метода при поисках рудных месторождений // Разведка и охрана недр. -2008. - № 4-5. - C. 46-50.

5. Гусева Н.В., Копылова Ю.Г., Шварцев С.Л. Гидрогеохимические поиски золотого оруденения на междуречье Ензорьяха и Юньяха (восточный склон Полярного Урала) // Разведка и охрана недр. -2010 . - № 11. - С. 54-58.

6. Мирошникова Л.В. Гидрогеохимические признаки и критерии сульфидного оруденения // Вестник Иркутского государственного технического университета. - 2011. - № 3 (50). C. $12-17$

7. Комплекс методов поисков золото-урановых рудопроявлений в условиях криолитозоны района Байкало-Амурской магистрали / А.В. Паршин, А.Е. Будяк, А.В. Блинов, А.Н. Костерев // Металлогения древних и современных океанов. - 2015. - № 21. C. $177-181$.

8. Глебова Л.В., Харлашкина А.К. Гидрохимический контроль как инструмент снижения негативного воздействия на окружающую среду при добыче углеводородного сырья // Геология, география и глобальная энергия. - 2015. - № 1 (56). - С. 165-170
(V, № 19), протекающие в области развития преимущественно карбонатных пород, отличаются ростом отношений $\mathrm{Ca} / \mathrm{Na}$ до 545,1 и $\mathrm{Ca} / \mathrm{Si}$ до 40,4 .

По содержаниям микрокомпонентов выделяются несколько водных объектов: р. Витим (№ 1), руч. Мысовой, p. Пыдриха, где выявлены повышенные содержания $\mathrm{Mn}$ (до 0,1 мг/дм $\left.{ }^{3}\right), \mathrm{Fe}$ (до 0,6 мг/дм $\left.{ }^{3}\right), \mathrm{Al}$ (до 0,3 мг/дм $\left.{ }^{3}\right)$, $\mathrm{Cr}$ (до 0,001 мг/дм ${ }^{3}$ ), $\mathrm{Cu}$ (до 0,001 мг/дм ${ }^{3}$ ), $\mathrm{Sc}$ (до 0,0003 мг/дм $\left.{ }^{3}\right), \mathrm{Ga}$ (до 0,0002 мг/дм $\left.{ }^{3}\right), \mathrm{Be}$ (до 0,00008 мг/дм³ ${ }^{3}$. Это свидетельствует о дополнительном наличии этих элементов в дренируемых горных породах.

Учитывая крайне малое время взаимодействия в системе вода - горная порода в водах не наблюдается значимых величин концентрирования элементов. А коэффициенты водной миграции по А.И. Перельману, отражающие интенсивность миграции элементов, показали, что очень сильную интенсивность имеют $\mathrm{Se}, \mathrm{I}$ и $\mathrm{Br}$, сильную - $\mathrm{Sb}, \mathrm{Mo}, \mathrm{Sr}$ и B, среднюю - Zn, Li, P, Ba, As, Cu, Y, Sc, Si, Mn, Rb, Ni, $\mathrm{Be}, \mathrm{Ge}, \mathrm{Co}, \mathrm{Cr}$, слабую (инертную) - Fe, V, Ga, Al, Ti, $\mathrm{Nb}, \mathrm{Zr0}, 009$. Отмечается переход селена из группы легкоподвижных элементов (по А.И. Перельману) в группу высокоподвижных. Рост концентраций селена по гидрогеохимическому профилю от $9,9 \cdot 10^{-5}$ до $3,9 \cdot 10^{-4}$ мг/дм ${ }^{3}$ может быть связан с его поступлением из вмещающих пород с сульфидной минерализацией в форме гидроселенид-иона $\left(\mathrm{HSeO}_{3}^{-}\right)$и оксида селена $\left(\mathrm{SeO}_{3}{ }^{2-}\right)$, что требует дополнительных исследований.

Исследования проводились при финансовой поддержке проекта ФНИ № 0331-2019-0025 «Геохимия, генезис и механизмы формирования состава подземных вод арктических районов осадочных бассейнов Сибири», Российского фонда фундаментальных исследований в рамках научного проекта № 18-05-70074 «Ресурсы Арктики» и Государственного Задания РФ «Наука» в рамках проекта № FSWW-0022-2020.

9. Ляпунов М.Ю. Эколого-геохимическая характеристика поверхностных вод золоторудного месторождения «Пионер» Амурской области // Известия Томского политехнического университета. Инжиниринг георесурсов. - 2015. - Т. 326. № 7 . - C. 44-50.

10. Горюхин М.В. Направления потенциального использования отработанных не обводненных карьеров полезных ископаемых Еврейской автономной области // Региональные проблемы: Материалы VII Всероссийской научной конференции / под ред. Е.Я. Фрисмана. - Биробиджан: Институт комплексного анализа региональных проблем Дальневосточного отделения РАН, 2018. - Т. 21. - № 3. - С. 49-54.

11. Анализ экологического состояния бухты Золотой рог залива Петра Великого / А.С. Зубцова, В.И. Петухов, Е.А. Вах, И.Л. Зубцова // Процессы в геосредах. - 2018. - № 3 (17). - С. 96-97.

12. Замана Л.В., Усманов М.Т., Борзенко С.В. Гидрохимия рек по трассе проектируемого нефтепровода «Восточная Сибирь Тихий океан» в междуречье Витима-Олекмы // Водные ресурсы. - 2007. - Т. 34. - № 3. - С. 345-355.

13. Составляющие гидрохимического режима вод р. Лены / М.И. Кузьмин, Е.Н. Тарасова, В.А. Бычинский, Е.Б. Карабанов, А.А. Мамонтов, Е.А. Мамонтова // Водные ресурсы. 2009. - T. 36. - № 4. - C. 440-451.

14. Особенности кислородного режима рек в бассейнах Волги, Оби и Лены / А.В. Гончаров, В.А. Исаев, Е.Е. Лобченко, И.П. Ничипорова // Водные ресурсы. - 2011. - Т. 38. - № 5. С. 564-570.

15. Ксенофонтова М.И., Легостаева Я.Б. Эколого-гидрохимическая характеристика рек юго-западной Якутии // Вестник Северо- 
Восточного федерального университета им. М.К. Аммосова. Серия: Науки о Земле. - 2016. - № 3 (3). - С. 58-68.

16. Георгиади А.Г., Тананаев Н.И., Духова Л.А. Гидрохимический режим реки Лены в августе 2018 г. // Океанология. 2019. - T. 59. - № 5. - C. 881-884.

17. Первые изотопно-гидрогеохимические данные по природным водам юго-восточного склона кряжа Чекановского (Арктические районы Сибирской платформы) / Д.А. Новиков, А.А. Максимова, А.Н. Пыряев, П.А. Ян // Известия Томского политехнического университета. Инжиниринг георесурсов. 2020. - T. 331. - № 11. - С. 157-167.

18. Григорьев Н.А. Распределение химических элементов в верхней части континентальной коры. - Екатеринбург: УрО РАН, 2009. $-383 \mathrm{c}$.

19. Сванидзе И.Г., Кремлева Т.А., Соромотин А.В. Воздействие подземных вод Западно-Сибирского артезианского бассейна на миграцию макро- и микроэлементов малых рек // Вестник ТюмГУ. Экология. - 2012. - № 12. - С. 55-63.

20. Государственная геологическая карта Российской Федерации. Масштаб 1:1000000. Лист О 49. - СПб.: Изд-во ВСЕГЕИ, 2012.

21. Габышев В.А., Ремигайло П.А., Габышева О.И. Пространственная структура и среда обитания фитопланктона реки Алдан // Известия Иркутского государственного университета. Серия: биология. Экология. - 2012. - № 2. - Т. 5. - С. 61-69.

22. Загорулько Н.А.Особенности основного ионного состава поверхностных вод бассейна р. Куда // Вестник ИрГТУ. 2014. - № 2 (85). - C. 61-67.

23. Перельман А.И. Геохимия ландшафта. 2-е изд. - М.: Высшая школа, $1975 .-342 \mathrm{c}$.

24. К вопросу о формах нахождения йода и селена в природных водах и их концентрирование на ландшафтно-геохимических барьерах / Е.М. Коробова, Б.Н. Рыженко, Е.В. Черкасова, Э.М. Седых, Н.В. Корсакова, В.Н. Данилова, С.Д. Хушвахтова, В.Ю. Березкин // Геохимия. - 2014. - № 6. - С. 554-568.

25. Trace metal geochemistry of remote rivers in the Canadian Arctic Archipelago / M. Colombo, K.A. Brown, J.D. Vera, B.A. Bergquist, K.J. Orians // Chemical Geology. - 2019. - V. 525. - P. 479-491.

26. Natural and anthropogenic factors affecting geochemistry of the Jialing and Yangtze Rivers in urban Chongqing, SW China / T. Qin, P. Yang, C. Groves, F. Chen, G. Xie, Z. Zhan // Applied Geochemistry. - 2018. - V. 98. - P. 448-458

27. A hydrochemistry and multi-isotopic study of groundwater origin and hydrochemical evolution in the middle reaches of the Kuye River basin / C. Fu, X. Li, J. Ma, L. Liu, M. Gao, Z. Bai // Applied Geochemistry. - 2018. - № 98. - P. 82-93.

28. Spatiotemporal variations of hydrogeochemistry and its controlling factors in the Gandaki River Basin, Central Himalaya Nepal /
R.R. Pant, F. Zhang, F.U. Rehman, G. Wang, M. Ye, C. Zeng, H. Tang // Science of the Total Environment. - 2018. - V. 622-623. P. 770-782.

29. Seasonal change of geochemical sources and processes in the Yenisei River: a Sr, Mg and Li isotope study / R.S. Hindshaw, R. Teisserenc, T.L. Dantec, N. Tananaev // Geochimica et Cosmochimica Acta. - 2019. - V. 255. - P. 222-236.

30. The use of major, trace elements and uranium isotopic ratio (234U/238U) for tracing of hydrogeochemical evolution of surface waters in the Andarax River catchment (SE Spain) / F. NavarroMartínez, F. Sánchez-Martos, A.S. García, J.G. Gallego // Journal of Geochemical Exploration. - 2020. - V. 213. - 106533.

31. Pollution, sources and environmental risk assessment of heavy metals in the surface AMD water, sediments and surface soils around unexploited Rona $\mathrm{Cu}$ deposit, Tibet, China / D. Qiao, G. Wang, X. Li, S. Wang, Y. Zhao // Chemosphere. - 2020. V. 248. -125988 .

32. Geochemical controls on magnesium and its speciation in various types of geothermal waters from typical felsic-rock-hosted hydrothermal systems in China / Q. Guo, M. Liu, L. Luo, K. Yan, W. Guo, G. Wu, W. Yan, Y. Wang // Geothermics. - 2019. V. 81. - P. 185-197.

33. Farhat S., Bali M., Kamel F. Geochemical and statistical studies of Mio-Pliocene aquifer's mineralization in Jerba Island, Southeastern Tunisia // Physics and Chemistry of the Earth, Parts A/B/C. - 2019. - V. 111. - P. 35-52.

34. Ashayeri N.Y., Keshavarzi B. Geochemical characteristics, partitioning, quantitative source apportionment, and ecological and health risk of heavy metals in sediments and water: a case study in Shadegan Wetland, Iran // Marine Pollution Bulletin. - 2019. V. $149 .-110495$

35. Крайнов С.Р., Рыженка Б.Н., Швец В.М. Геохимия подземных вод. - М.: Наука, 2004. - 677 с

36. Brookins D.G. Eh-pH diagrams for geochemistry. - Berlin; Heidelberg: Springer-Verlag, 1988. - $184 \mathrm{p}$.

37. Howard III J. H. Geochemistry of selenium: formation of ferroselite and selenium behavior in the vicinity of oxidizing sulfide and uranium deposits // Geochimica et Cosmochimica Acta. - 1977. - V. 41. - P. 1665-1678.

38. Atlas of Eh-pH diagrams. Intercomparison of thermodynamic databases National Institute of Advanced Industrial Science and Technology Research Center for Deep Geological Environments Naoto Takeno. - Japan, 2005. - № 419. - 287 c.

Поступила 09.06.2021 г.

\section{Информация об авторах}

Новиков Д.А., кандидат геолого-минералогических наук, заведующий лабораторией гидрогеологии осадочных бассейнов Сибири Института нефтегазовой геологии и геофизики им. А.А. Трофимука СО РАН; доцент кафедры геологии месторождений нефти и газа и кафедры общей и региональной геологии Новосибирского национального исследовательского государственного университета.

Максимова A.A., студент Новосибирского национального исследовательского университета.

Напреев Д.В., директор производственной геофизической экспедиции ООО Научно-производственного предприятия геофизической аппаратуры «Луч».

Копылова Ю.Г., кандидат геолого-минералогических наук, старший научный сотрудник проблемной научноисследовательской лаборатории гидрогеохимии Инженерной школы природных ресурсов Национального исследовательского Томского политехнического университета.

Хващевская A.A., кандидат геолого-минералогических наук, доцент, заведующая проблемной научноисследовательской лабораторией гидрогеохимии Инженерной школы природных ресурсов Национального исследовательского Томского политехнического университета, доцент отделения геологии Инженерной школы природных ресурсов Национального исследовательского Томского политехнического университета. 
UDK 543.3:550.4(282.256.615)

\title{
GEOCHEMICAL FEATURES OF NATURAL WATERS IN THE BASIN OF THE VITIM RIVER (WESTERN REGIONS OF PATOM UPLAND)
}

Dmitry A. Novikov1,2,

NovikovDA@ipgg.sbras.ru

\section{Anastasia A. Maksimova ${ }^{1}$,} rock.nastaya64@gmail.com

Denis V. Napreev ${ }^{3}$, ndv@mail.ru

\section{Yulia G. Kopylova ${ }^{4}$,} unpc_voda@mail.ru

\author{
Albina A. Khvacshevskaya ${ }^{4}$, \\ unpc_voda@mail.ru \\ 1 Trofimuk Institute of Petroleum Geology and Geophysics of SB of RAS, \\ 3/6, Koptyug avenue, Novosibirsk, 630090, Russia. \\ 2 Novosibirsk State University, \\ 1, Pirogov street, Novosibirsk, 630090, Russia. \\ ${ }^{3}$ Scientific production enterprise of geophysical equipment «Looch», \\ 49, Geologicheskaya street, Novosibirsk, 630010, Russia. \\ ${ }^{4}$ National Research Tomsk Polytechnic University, \\ 30, Lenin avenue, Tomsk, 634050, Russia.
}

The relevance of this study is related to obtaining the first results of comprehensive geochemical studies of natural waters of the Vitim river basin in the western regions of the Patom upland. Taking into account a large number of mineral deposits (gold, iron, titanium, and lead), two applied aspects of using the studies performed arise. The first is related to the adaptation of the hydrogeochemical method of prospecting ore deposits. The second is related to the assessment of the anthropogenic impact of the development of mineral deposits and the operation of mining and processing enterprises on the environment.

The aim of the research is to identify the geochemical characteristics of the waters of the Vitim river basin and assess the possible sources of elements in the water.

Methods. Field testing was carried out in accordance with generally accepted methods. Chemical analytical studies were performed by titrimetry, ion chromatography and inductively coupled plasma mass spectrometry. The degree of concentration of chemical elements in natural waters was assessed by calculating the concentration coefficients (Kki) and water migration according to A.I. Perelman (Kx1).

Results. The paper introduces the first results of integrated hydrogeochemical studies of natural waters in the basin of the Vitim river (Patom upland). With respect to chemical composition, $\mathrm{SO}_{4}-\mathrm{HCO}_{3} \mathrm{Mg}-\mathrm{Ca}$ and $\mathrm{HCO}_{3} \mathrm{Mg}-\mathrm{Ca}$ waters with total mineralization from 10 to $298 \mathrm{mg} / \mathrm{dm}^{3}$ dominate. The waters are characterized by $\mathrm{pH}$ from neutral to weakly alkaline $(6,6-8)$ and the oxidation conditions of geochemical setting with Eh from $+155,5$ to $+215,9 \mathrm{mV}$ and $\mathrm{O}_{2}$ sol content from 4,9 to $8,4 \mathrm{mg} / \mathrm{dm}^{3}$. The calculated water migration coefficients (average values) for chemical elements in the studied waters were ranged in a decreasing sequence as follows: very strong migration in-

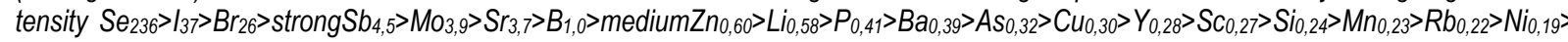
$B e_{0,18}>\mathrm{Ge}_{0,16}>\mathrm{Co}_{0,16}>\mathrm{Cr}_{0,13}>$ weak (inert) migration intensity $>\mathrm{Fe}_{0,075}>\mathrm{V}_{0,06}>\mathrm{Ga}_{0,049}>\mathrm{Al}_{0,029}>\mathrm{Ti}_{0,01}>\mathrm{Nb}_{0,015}>\mathrm{Zr}_{0,009}$. The profile revealed a complicated hydrogeochemical field which is affected mainly by natural factors.

\section{Key words:}

Natural waters, hydrochemistry, intensity of water migration of elements, river Vitim basin, Patom upland, Siberian platform.

The research was financially supported by the FSR no. 0331-2019-0025, the Russian Foundation for Basic Research as part of the scientific project no. 18-05-70074 «Arctic Resources» and State Assignment of the Russian Federation «Science» within the project no. FSWW-0022-2020.

\section{REFERENCES}

1. Khain V.E. Tektonika kontinentov i okeanov (god 2000) [Tectonics of continents and oceans (year 2000)]. Moscow, Nauchny mir Publ., 2001. 606 p.

2. Ivanov A.I. Riphean-paleozoic ore formation in the Baikal-Patom gold-mining province. Prospect and protection of mineral resources, 2009, no. 12, pp. 3-10. In Rus.
3. Arkhangelskaya V.V. Mineral deposits of Patomsky mountainous and their structural position. Prospect and protection of mineral resources, 2012, no. 4, pp. 7-10. In Rus.

4. Kolotov B.A. Scientific basis of the hydrogeochemical method in the search for ore deposits. Razvedka i okhrana nedr, 2008, no. 4-5, pp. 46-50. In Rus.

5. Guseva N.V., Kopylova Yu.G., Shvartsev S.L. Hydrogeochemical prospecting of gold mineralization in the Enzory-akha and Yunyakha interfluves (the eastern slope of the Polar Ural). Pro- 
spect and protection of mineral resources, 2010, no. 11, pp. 54-58. In Rus.

6. Miroshnikova L.V. Hydrogeochemical features and criteria of sulfide mineralization. Vestnik Irkutskogo gosudarstvennogo tekhnicheskogo universiteta, 2011, no. 3 (50), pp. 12-17. In Rus.

7. Parshin A.V., Budyak A.E., Blinov A.V., Kosterev A.N. A set of methods for searching for gold-uranium ore occurrences in the permafrost zone of the Baikal-Amur Railway. Metallogeniya drevnikh i sovremennykh okeanov, 2015, no. 21, pp. 177-181. In Rus.

8. Glebova L.V., Kharlashkina A.K. Hydrochemical monitoring as a tool to reduce adverse impact on the environment in the extraction of hydrocarbon raw material. Geology, geografy and global energy, 2015, no. 1 (56), pp. 165-170. In Rus.

9. Lyapunov M.Yu. Ecological and geochemical characteristics of surface waters of the Pioner gold ore deposit in the Amur Region. Bulletin of the Tomsk Polytechnic University. Geo Assets Engineering, 2015, vol. 326, no. 7, pp. 44-50. In Rus.

10. Goryukhin M.V. Napravleniya potentsialnogo ispolzovaniya otrabotannykh neobvodnennykh karyerov poleznykh iskopayemykh Evreyskoy avtonomnoy oblasti [Areas of potential use of waste not flooded quarries of minerals on the example of the Jewish Autonomous Region]. Materialy VII Vserossiyskoy nauchnoy konferentsii [Materials of the VII All-Russian Scientific Conference]. Ed. by E.Ya. Frisman. Birobidzhan, Institute for the Comprehensive Analysis of Regional Problems of the Far Eastern Branch of the Russian Academy of Sciences Publ., 2018. Vol. 21, no. 3, pp. 49-54.

11. Zubtsova A.S., Petukhov V.I., Vakh E.A., Zubtsova I.L. Analysis of the ecological condition of the Golden horn bay of Peter the Great bay. Processes in GeoMedi, 2018, no. 3 (17), pp. 96-97. In Rus.

12. Zamana L.V., Usmanov M.T., Borzenko S.V. Hydrochemistry of rivers along the route of the projected oil pipeline «Eastern Siberia - Pacific Ocean» in the Vitim-Olekma interfluve. Vodnye resursy, 2007, vol. 34, no. 3, pp. 345-355. In Rus.

13. Kuzmin M.I., Tarasova E.N., Bychinsky V.A., Karabanov E.B., Mamontov A.A., Mamontova E.A. Components of the hydrochemical regime of the river Lena. Vodnye resursy, 2009, vol. 36, no. 4, pp. 440-451. In Rus.

14. Goncharov A.V., Isaev V.A., Lobchenko E.E., Nichiporova I.P. Features of the oxygen regime of rivers in the Volga, $\mathrm{Ob}$ and Lena basins. Vodnye resursy, 2011, vol. 38, no. 5, pp. 564-570. In Rus.

15. Ksenofontova M.I., Legostaeva Ya.B. Ecological and hydrological characteristics of rivers of South West Yakutia. Vestnik of NorthEastern Federal University. Series «Earth Sciences», 2016, no. 3 (3), pp. 58-68. In Rus.

16. Georgiadi A.G., Tananaev N.I., Dukhova L.A. Hydrochemical regime of the Lena River in August 2018. Okeanologiya, 2019, vol. 59, no. 5, pp. 881-884. In Rus.

17. Novikov D.A., Maksimova A.A., Pyrayev A.N., Yan P.A. Firs isotope-hydrogeochemical data on the natural waters of the southeast slope of the Chekanovsky ridge (Arctic areas of the Siberian Platform). Bulletin of the Tomsk Polytechnic University. Geo Assets Engineering, 2020, vol. 331, no. 11, pp. 157-167. In Rus.

18. Grigoryev N.A. Raspredelenie khimicheskikh elementov v verkhney chasti kontinentalnoy kory [Chemical element distribution in the upper continental crust.]. Ekaterinburg, UB RAS Publ., 2009. 383 p. In Rus.

19. Svanidze I.G., Kremleva T.A., Soromotin A.V. Influence of the artesian basin groundwater of West Siberia on the migration of macroand microelements in minor rivers. Bulletin of the Tyumen State University Herald. Ecology, 2012, no. 12, pp. 55-63. In Rus.

20. Gosudarstvennaya geologicheskaya karta Rossiyskoy Federatsii. Masshtab 1:1000000. List O 49 [State geological map of the Russian Federation. Scale 1:1000000. Sheet O 49.]. St-Petersburg. VSEGEI Publ. house, 2012

21. Gabyshev V.A., Remigaylo P.A., Gabysheva O.I. Spatial structure and habitat conditions of phytoplankton of the Aldan River. Bulle- tin of the Irkutsk State University. Biology. Ecology, 2012, vol. 5, no. 2, pp. 61-69. In Rus.

22. Zagorulko N.A. Features of basic ionic composition of the Kuda river basin surface waters. Bulletin of ISTU, 2014, no. 2 (85), pp. 61-67. In Rus.

23. Perelman A.I. Geokhimiya landshafta [Landscape geochemistry]. $2^{\text {nd }}$ ed. Moscow, Vysshaya shkola Publ., 1975. $342 \mathrm{p}$

24. Korobova E.M., Ryzhenko B.N., Cherkasova E.V., Sedykh E.M., Korsakova N.V., Danilova V.N., Khushvakhtova S.D., Berezkin V.Yu. To the question of the forms of iodine and selenium in natural waters and their concentration on landscape-geochemical barriers. Geokhimiya, 2014, no. 6, pp. 554-568. In Rus.

25. Colombo M., Brown K.A., Vera J.D., Bergquist B.A., Orians K.J. Trace metal geochemistry of remote rivers in the Canadian Arctic Archipelago. Chemical Geology, 2019, no. 525, pp. 479-491.

26. Qin T., Yang P., Groves C., Chen F., Xie G., Zhan Z. Natural and anthropogenic factors affecting geochemistry of the Jialing and Yangtze Rivers in urban Chongqing, SW China. Applied Geochemistry, 2018, no. 98, pp. 448-458.

27. Fu C., Li X., Ma J., Liu L., Gao M., Bai Z., A hydrochemistry and multi-isotopic study of groundwater origin and hydrochemical evolution in the middle reaches of the Kuye River basin. Applied Geochemistry, 2018, no. 98, pp. 82-93.

28. Pant R.R., Zhang F., Rehman F.U., Wang G., Ye M., Zeng C., Tang H. Spatiotemporal variations of hydrogeochemistry and its controlling factors in the Gandaki River Basin, Central Himalaya Nepal. Science of the Total Environment, 2018, vol. 622-623, pp. 770-782.

29. Hindshaw R.S., Teisserenc R., Dantec T.L., Tananaev N. Seasonal change of geochemical sources and processes in the Yenisei River: A Sr, $\mathrm{Mg}$ and Li isotope study. Geochimica et Cosmochimica Acta, 2019, vol. 255, pp. 222-236.

30. Navarro-Martínez F., Sánchez-Martos F., García A.S., Gallego J.G. The use of major, trace elements and uranium isotopic ratio (234U/238U) for tracing of hydrogeochemical evolution of surface waters in the Andarax River catchment (SE Spain). Journal of Geochemical Exploration, 2020, vol. 213, 106533.

31. Qiao D., Wang G., Li X., Wang S., Zhao Y. Pollution, sources and environmental risk assessment of heavy metals in the surface AMD water, sediments and surface soils around unexploited Rona $\mathrm{Cu}$ deposit, Tibet, China. Chemosphere, 2020, vol. 248, 125988.

32. Guo Q., Liu M., Luo L., Yan K., Guo W., Wu G., Yan W., Wang Y. Geochemical controls on magnesium and its speciation in various types of geothermal waters from typical felsic-rockhosted hydrothermal systems in China. Geothermics, 2019, vol. 81 , pp. 185-197.

33. Farhat S., Bali M., Kamel F. Geochemical and statistical studies of Mio-Pliocene aquifer's mineralization in Jerba Island, Southeastern Tunisia. Physics and Chemistry of the Earth, Parts $A / B / C$, 2019, vol. 111, pp. 35-52.

34. Ashayeri N.Y., Keshavarzi B. Geochemical characteristics, partitioning, quantitative source apportionment, and ecological and health risk of heavy metals in sediments and water: A case study in Shadegan Wetland, Iran. Marine Pollution Bulletin, 2019, vol. 149, 110495 .

35. Kraynov S.R., Ryzhenka B.N., Shvets V.M. Geokhimiya podzemnykh vod [Geochemistry of groundwater]. Moscow, Nauka Publ., 2004. 677 p.

36. Brookins D.G. Eh-pH diagrams for geochemistry. Berlin, Heidelberg, Springer-Verlag, 1988. $184 \mathrm{p}$.

37. Howard III J.H. Geochemistry of selenium: formation of ferroselite and selenium behavior in the vicinity of oxidizing sulfide and uranium deposits. Geochimica et Cosmochimica Acta, 1977, vol. 41, pp. 1665-1678.

38. Atlas of Eh-pH diagrams. Intercomparison of thermodynamic databases. Japan, National Institute of Advanced Industrial Science and Technology Research Center for Deep Geological Environments Naoto Takeno, 2005. No. 419, 285 p. 


\section{Information about the authors}

Dmitry A. Novikov, Cand. Sc., head of the laboratory, Trofimuk Institute of Petroleum Geology and Geophysics of Siberian Branch of Russian Academy of Sciences; associate professor, Novosibirsk State University.

Anastasia A. Maksimova, student, Novosibirsk State University.

Denis V. Napreev, chief of the worksite geophysical expedition, Scientific production enterprise of geophysical equipment «Looch».

Yulia G. Kopylova, Cand. Sc., senior researcher, National Research Tomsk Polytechnic University.

Albina A. Khvacshevskaya, Cand. Sc., head of the scientific laboratory, National Research Tomsk Polytechnic University. 